\title{
Liofil és liofób kolloidok diszperziók elektromos felületi tulajdonságai: a liotróp sorok érvényessége* 1. Elektrokinetikai potenciál ${ }^{* *}$
}

\author{
MANILO Maryna ${ }^{\mathrm{a}, \mathrm{b}}$, MÉSZÁROS Renáta ${ }^{\mathrm{a}}$, LEBOVKA Nyikoláj ${ }^{\mathrm{b}}$ és BÁRÁNY Sándora,c,d \\ a Alkalmazott Földtudományi Kutatóintézet, Miskolci Egyetem, 3515 Miskolc-Egyetemváros, Magyaroszág, \\ ${ }^{b}$ Biokolloidok Kémiája Kutatóintézet, Ukrán TA, Vernadszkij sugárút 42, Kijev, Ukrajna, \\ ${ }^{c}$ MTA-ME Anyagtudományi Kutatócsoport,3515 Miskolc, Egyetemváros, Magyarország \\ ${ }^{d}$ Kémiai Intézet, Miskolci Egyetem, 3515 Miskolc-Egyetemváros, Magyarország
}

\section{Bevezetés. Irodalmi áttekintés}

Az ionok kémiai természete és hidratációja jelentősen be-

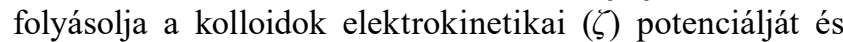
felületi vezetését elsősorban két tényező hatására. (1) A rosszabbul hidratált (ellen) ionok jobban adszorbeálódnak a felületen, mint a jól hidratált ionok, növekvő mértékben halmozódnak fel a Stern-rétegben, ami a részecskék $\zeta$ - potenciáljának és felületi vezetésének csökkenéséhez vezet. (2) A felület hidratáltságának mértéke határozza meg a hasadási sík pozícióját és ennek megfelelően a részecskék elektrokinetikai potenciálját.

Az ionok hidratációja és az elektroforézis, illetve a kolloidok állandósága közötti összefüggés az ún. liotróp vagy Hofmeister sorokban tükröződik. A probléma még 1888-ig nyúlik vissza, amikor Hofmeister a vizsgált elektrolitokat egy sorrendben helyezte el a tojásfehérje kicsapatása hatékonyságának függvényében. Az anionok esetében az egyenes Hofmeister sor a következő ${ }^{1,2,3}$ :

$$
\begin{gathered}
\mathrm{CO}_{2}{ }^{3-}<\mathrm{SO}_{4}{ }^{2-}<\mathrm{F}^{-}<\mathrm{CH}_{3} \mathrm{COO}^{-}<\mathrm{Cl}^{-}<\mathrm{Br}^{-}< \\
\mathrm{NO}_{3}{ }^{-}<\mathrm{ClO}_{4}{ }^{-}<\mathrm{SCN}^{-}
\end{gathered}
$$

Például a baloldalon lévő anionok hajlamosak kicsapatni oldatokból a fehérjéket, míg a jobb oldalon elhelyezkedő ionok növelik a fehérjék oldhatóságát. A klór- ion a kettő közötti választóvonal. A kationok direkt Hofmeister sora az alábbi ${ }^{1,3}$ :

$$
\mathrm{Cs}^{+}<\mathrm{Rb}^{+}<\mathrm{K}^{+}<\mathrm{Na}^{+}<\mathrm{Li}^{+}
$$

Általában az anionok hatása erőteljesebb és specifikusabb, mint a kationoké. Ez azzal magyarázható, hogy az anionok összességükben nagyobbak és jobban polarizálhatók, mint a kationok.

Mint említettük, a nagyobb kristálysugárral rendelkező ionok általában jobban kötődnek a felülethez, esetenként nagyobb mennyiségben adszorbeálódnak és ennek következtében hatékonyabban csökkentik a $\zeta$ - potenciál értékét és kisebb kritikus koagulációs koncentrációt mutatnak. A fen- ti egyenes Hofmeister sor a kationok "csupasz" rádiuszával korrelál és negatív töltésjelü liofób felületek esetében figyelhető meg. A liotróp sor ezen egyszerü magyarázata az ionok hidratációjából indul ki: a kisebb kristálysugárral rendelkező ionok erősebben kötik meg a vízmolekulákat és így effektivé megnagyobbodva, nem tudnak olyan közel kerülni a felületi töltéssel rendelkező csoportokhoz, mint a kisebb ionok. A két ellentétes töltés asszociációjának értelmezésében a legközelebbi ion-ion (centre-to-centre) távolságot kell figyelembe venni, ami nem egyenlő az ionok sugarának összegével ${ }^{4,5}$

Az utóbbi évek kísérletei azt bizonyították, hogy az oldott ionok nem bontják meg a víz hidrogén-kötéseinek hálóját,az első hidrát rétegen túli tartományban. Kevéssé valószínü, hogy a liotróp sorok megjelenését az ionok által a vízben létrehozott szerkezeti változások hozzák létre ${ }^{6,7}$ Elmondható, hogy nem létezik egy unikális Hofmeister sor: az ionok elhelyezkedésének sorrendjét befolyásolja a felület természete (töltéselőjele és töltéssürüsége, polaritása, liofób vagy liofil jellege), az elektrolitok típusa és koncentrációja, a pH-értéke és a hömérséklet. ${ }^{8}$ A megválasztott paraméterek függvényében a Hofmeister sor lehet egyenes, fordított vagy részben fordított ${ }^{9,10}$.

$\mathrm{Az}$ ionok elhelyezkedési sorrendjében szerepet játszanak mind az elektrosztatikus, mind a nem-elektrosztatikus erők. A diffúz elektromos kettősréteg szerkezetét leíró GuyChapman- féle elmélet, amely indifferensnek tekinti mind az ellenionokat és mind ko-ionokat, nem értelmezi az ionok specifikus hatását. A Stern elmélet, amely figyelembe veszi az ionok specifikus adszorpcióját, alkalmasnak tünik a liotróp sorok értelmezésére, de az elmélet csak a felülettel közvetlenül érintkezésbe lévő vízrétegben elhelyezkedő ionok viselkedését vizsgálja. Ennek az oka az, hogy az ionok specifikus kölcsönhatása csak kis távolságokon valósul meg.

Annak a kérdésnek a megválaszolása, pontosan milyen mechanizmus szerint vonzódnak vagy taszítódnak az ionok az adott felülethez/felülettől, összetett: ez a direkt ion-felület és

\footnotetext{
* Prof. Dr. Bárány Sándor: akmbsab@uni-miskolc.hu

** A közlendő tanulmányunk a szerzők J. Molecular Liquids, 276 (2019) 875-884 folyóiratban közölt cikkének bővített változata
} 
indirekt hidratációs kölcsönhatások közötti verseny függvénye ${ }^{11}$. Egyes elméletek az ionok felülethez való affinitását ezek polarizálhatóságával magyarázzák, ami arányos az ion térfogatával ${ }^{12}$. Az utóbbi szerzők tárgyalták különböző kationok és anionok direkt, indirekt és változó Hofmeister sorok függését a felület töltéssürüségétől és liofil/liofób jellegétől. Az ionok helyét a sorban szerintük a felületi feszültség változása és nagy távolságokon ható (long-range) elektrosztatikus erők határozzák meg.

Vegyünk szemügyre néhány jellegzetes eredményt az ionok természetének hatásáról kolloidok elektrokinetikai potenciáljára. Szilícium dioxid részecskék $\zeta$ - potenciáljának változásai $\mathrm{LiCl}, \mathrm{NaCl}, \mathrm{KCl}$ és $\mathrm{CsCl}$ oldatokban az alábbiakban összegezhetők. A gyengébben hidratált $\mathrm{K}^{+}$és $\mathrm{Cs}^{+}$ionok nagyobb mennyiségben adszorbeálódnak a felületen, mint a jól hidratált $\mathrm{Li}+$ és $\mathrm{Na}+$ ionok és kisebb $\zeta$ - potenciált eredményeznek magas pH értékeknél. Nagy elektrolit-koncentrációknál és alacsony $\mathrm{pH}$ értékeknél az ellenionok olyan mértékben adszorbeálódnak, hogy megváltoztatják a felület potenciáljának előjelét, negatívról pozitívra. Az izoelektromos pont (IEP) eltolódása összefügg az ellenionok hidratációjával, a kevésbé hidratált ionok nagyobb IEP eltolódást eredményeznek ${ }^{13}$

AFM mérések alapján a $\mathrm{Cs}^{+}$ionok preferenciális adszorpcióját $\mathrm{SiO}_{2}$ felületén azzal hozták összefüggésbe, hogy a neutrális felületi szilanol csoportok gyengén hidratáltak és a kevésbé hidratált ellenionok kiszorulnak az oldatból, liofób kölcsönhatásba lépve a felületi csoportokkal. Ugyanilyen típusú kölcsönhatások az oldatban tartják a jól hidratált, $\mathrm{Na}^{+}$és $\mathrm{Li}^{+}$ionokat. A pH növekedésével a deprotonizált szilanol csoportok körül erősen kötött hidrát burok képződik, $\mathrm{a} \mathrm{Cs}^{+}$ionok kiszorulnak a felületröl és a kis ionok adszorpciója lesz preferált ${ }^{14}$.

Saka és Güler direkt liotróp sort figyeltek meg montmorrilonit részecskék elektrokinetikai potenciáljának és töltésének változásaiban alkáli fém kloridok oldataiban különböző pH értékeknél, azaz a potenciál abszolút értéke jelentősen csökkent a $\mathrm{Li}^{+}>\mathrm{Na}^{+}>\mathrm{K}^{+}>\mathrm{Rb}^{+}>\mathrm{Cs}^{+}$sorban ${ }^{15} \mathrm{Az}$ elektrolitok koncentrációjának növelésével $\left(10^{-4} \mathrm{M}\right.$ és $10^{-1} \mathrm{M}$ között) a $\zeta$ - potenciál fokozatosan csökkent. Potenciometrikus, elektrokinetikai és koaguláltatási vizsgálatok eredményei alapján kimutatták, hogy a nullatöltés pontja feletti $\mathrm{pH}$ tartományban az alkálifém kloridoknak a $\mathrm{TiO}_{2}$ (rutil) részecskék $\zeta$ - potenciálra kifejtett hatása reverzibilis liotróp sornak felelnek meg, azaz $\mathrm{Li}^{+}>\mathrm{K}^{+}>\mathrm{Cs}^{+}{ }^{16} \mathrm{Az}$ indirekt Hofmeister sort a felület töltéselőjelének és kémiai természetének változásával magyarázták.

$\mathrm{A}^{17}$ szerzők vizsgálták a felület természetének hatását a kolloid rendszerekben megnyilvánuló a Hofmeister effektusokra. Kimutatták, hogy a sorrend változását nem csak a felület töltésjelének változása, hanem liofil/liofób jellegének változása is elöidézheti. pH- függő töltéssel jellemezhető felületek esetében a hasonló töltésjelü liofób felületeknél megfigyelt direkt Hofmeister sor megfordul, ha a felüle- tet liofil jellegét növeljük. Számos közelmúltban publikált cikkben kimutatták, hogy a felület töltésjele, kémiai természete/polaritása, hőmérséklet, só-koncentráció és $\mathrm{pH}$ függvényében az ionok liotróp sorokban való elhelyezkedése megváltoztatható ${ }^{18,19,20}$. A régebben univerzálisnak hitt Hofmeister sor helyett megjelent a direkt, részben megváltozott és reverzibilis sorok egész spektruma. $\mathrm{A}^{21}$ szerzők részletesen vizsgálták a publikált kísérleti adatokat molekuláris dinamikai szimuláció, a Poisson-Bolzmann elmélet szemszögéből, valamint AFM mérések együttes értékelésével. Szimulálták az ion-felület kölcsönhatási potenciálokat nem-poláris, poláris és jelentős töltésű felületi csoportokkal rendelkező felületek esetében halid anionokból és alkáli fém kationokból álló só-oldatokban. Az eredmények szerint egyenes Hofmeister sorok liofób negatív töltésjelü felületek esetében realizálódnak. A felület negatívról pozitívra való megváltoztatása, illetve a liofób felület liofilizálása a pH vagy só-koncentrációjának változtatásával, a sor inverziójához vezet.

A felület hidratációjának mértéke a legfontosabb paraméter, amely meghatározza a hasadási sík távolságát a felülettől és a kolloidok $\zeta$ - potenciáljának értékét. Ennek az óriási, szerteágazó problémának tárgyalása, túlhaladja az összefoglalónk kereteit. A fontosabb eredmények összegezését lásd az egyik szerző áttekintő tanulmányában ${ }^{22}$. .Különböző kémiai természetü (latexek, $\mathrm{AgI}, \mathrm{Sb}_{2} \mathrm{~S}_{3}, \mathrm{SiO}_{2}, \mathrm{FeO}(\mathrm{OH}), \mathrm{ZrO}_{2}$, $\mathrm{CeO}_{2}, \mathrm{SiC}$, TiC, bentonit, kaolin, csillámpala, paligorszkit, olaj/víz emulziók és élesztősejtek), formájú (gömb, ellipszis, henger vagy tű alakú) és méretü (nanométerektől mikronokig) kolloidok elektromos kettősrétegének szerkezetét vizsgálták a felületi töltéssürüség, elektrokinetikai potenciál és felületi vezetőképesség meghatározása alapján. Kimutatták, hogy kolloidok döntő többségének $\zeta$ - potenciál értéke, még ha ezt korrigálták is az egész diffúz réteg polarizációjának figyelembevételével (Dukhin-Semenikhin szerint), nagyságrendekkel kisebb, mint a számított felületi potenciál vagy (az elektromos vezetésmérésekből) meghatározott Stern-potenciál nagysága. A hasadási síkban lokalizált töltések száma, az ún. elektrokinetikai töltés csak kis hányada (jellegzetesen 1-10\%) a potenciometrikus vagy konduktometriás titrálással mért felületi töltéssürüségnek, ami a felületen képződött vastag hidrát rétegek képződésére utal. A kettősréteg hidrodinamikailag immobil (azaz a Stern-réteg és hasadási sík közötti térrészben) részében lokalizált ellenionok ugyanakkor az elektromos térben megtartják jelentős mozgékonyságukat, ami összemérhető a tömbfázisban lévő ionok mozgékonyságával ${ }^{22,23}$.

Nyilvánvaló, hogy a felület liofil jellegének növelése liofil funkciós csoportok (-O-, - $\left.\mathrm{OH},-\mathrm{NH}_{2},-\mathrm{COOH}\right)$ beépítésével, felületaktív anyagok adszorpciója vagy a kevésbé hidratált ellenionokat jobban hidratált ellenionokkal való kicserélése révén, a hasadási síknak a tömbfázis irányába való eltolódásához vezet, ami a $\zeta$ - potenciál csökkenésével párosul. Ennek fordítottja pedig, azaz felület-közeli hidrát rétegek roncsolása, vékonyítása a hasadási síkot a felület felé tolja el, ami a $\zeta$ - potenciál növekedéséhez vezet. A hidrát rétegek 
roncsolását melegítéssel, dehidratáló szerek, pl. alkoholok, szulfát-ionok adagolásával vagy jobban hidratált ionok kevésbé hidratált ionokkal való kicserélésével érhető el.

Tanulmányunkban részletesen vizsgáltuk alkáli fém kloridok és szulfátok hatását modell és gyakorlatilag fontos liofób (latexek) és liofil (aeroszil, bentonit, laponit, cirkónium dioxid) diszpergált részecskék elektrokinetikai potenciáljára és felületi vezetőképességre vizes oldatokban. Kiemelt figyelmet fordítottunk a Hofmeister sorok érvényességének vizsgálatára, valamint a dehidratáló hatással nem rendelkező (Cl-) és rendelkező $\left(\mathrm{SO}_{4}{ }^{2-}\right)$ anionokat tartalmazó elektrolitok eltérő viselkedésének tisztázására.

\section{Anyagok és módszerek}

\section{Polisztirol latex (PS) felületi szulfo- csoportokkal}

A Furasawa módszerrel ${ }^{23}$ (a polimerizáció iniciátorként kálium-perszulfátot alkalmaznak) előállított PS részecskéket vizsgáltunk. A részecskék szűk méreteloszlást mutattak, $0,55 \pm 0,05 \mu \mathrm{m}$ átlag-átmérővel. A potenciometrikus titrálással meghatározott felületi töltéssürüség $7,2 \cdot 10^{-2} \mathrm{C} \cdot \mathrm{m}^{-2}$ értéknek felelt meg.

\section{Karboxil-latex}

Monodiszperz, karboxil felületi csoportokkal funkcionalizált (koncentrációjuk 2,0110-6 $\mathrm{mol} \mathrm{m}^{-2}$ ) polisztirol latexet (PS-COOH) 1,43 $\pm 0,05 \mu \mathrm{m}$ átlag-átmérővel használtunk. A mintát Dr. Yulia Skurkis-tól, az Orosz TA szentpétervári Makromolekuláris Anyagok kutatóintézete főmunkatársától kaptuk.

\section{Aeroszil részecskék}

Kutatásunkban Aerosil-300 márkájú (Evonik Industries AG, Németország) liofil részecskéket használtunk, melynek $\mathrm{SiO}_{2}$ tartalma $>99.8 \%$, fajlagos felülete $300 \mathrm{~m}^{2} / \mathrm{g}$, átlag átméröje $7 \mathrm{~nm}$ volt. A 20 perces ultrahangos kezelésnek alávetett szuszpenzióban a kiinduló részecskék gyorsan aggregálódtak, és 10-15 perc elteltével a képződött aggregátumok mérete elérte a 40-50 nm-t.

\section{Cirkónium dioxid}

$\mathrm{ZrO}_{2}$ részecskéket cirkónium nitrát $450{ }^{\circ} \mathrm{C}$ hőmérsékleten megvalósított 6 órai hevítésével állítottunk elő. A terméket mozsárban morzsoltuk, desztillált vízben diszpergáltuk, szedimentációval frakcionáltuk és 15 perces ultrahangos kezelésnek vetettük alá $35 \mathrm{kHz}$ frekvencia mellett hideg vizes fürdőben. Kísérleteinkhez a néhány napig nem ülepedő frakciót használtuk, ezek átlag átmérője $\approx 1,2 \mu \mathrm{m}$ volt. A minta potenciometrikus titrálással meghatározott nullatöltés pontja széles $\mathrm{KCl}$ koncentráció intervallumban $\left(10^{-}\right.$ ${ }^{3}$ - $\left.10^{-1} \mathrm{M}\right) \mathrm{pH} 4,0$ értéknek felelt meg. pH 9-nél a felület töltéssürüsége $\mathrm{a} \approx 12 \cdot 10^{4} \mu \mathrm{C} \cdot \mathrm{m}^{-2}$ értéket érte el.

\section{Laponit}

A Laponite RD, Lap, (Rockwood Additives Ltd., UK) egy szintetikus agyagásvány az alábbi képlettel ${ }^{24}$ : $\mathrm{Na}_{+0.7}\left[\left(\mathrm{Si}_{8} \mathrm{Mg}_{5.5} \mathrm{Li}_{0.3}\right) \mathrm{O}_{20}(\mathrm{OH})_{4}\right]_{-0.7}$. Az irodalmi adatok alapján ${ }^{25}$, a nitrogén adszorpcióból meghatározott fajlagos felülete $370 \mathrm{~m}^{2} / \mathrm{g}$, sürüsége $\approx 2.53 \mathrm{~g} / \mathrm{cm}^{3}$. A Lap $1 \mathrm{~nm}$ vastagságú és 25-30 nm átlag átméröjü diszkosz formájú korongokat képez. Ezek töltése vizes oldatokban heterogén: a korong felületén permanens negatív töltésekkel rendelkezik, míg az élek töltése pH-függő és pozitív savas közegben. A negatív felületi töltés, ami meghatározza az ásvány ioncserélő kapacitását, $0.75 \mathrm{mmol} / \mathrm{g}$ értéket ér el. A Lap szuszpenziókat meghatározott mennyiségű részecske desztillált vízhez való hozzáadásával állítottuk elö, a képződött szuszpenziót 5 percig hideg vizes fürdőben ultrahangos kezelésnek vetettük alá.

\section{Na-bentonit}

Mád lelöhelyről származó bentonitot tisztítottuk sósavas kezeléssel, többszöri mosással desztillált vízben, majd dörzsöléssel aprítottuk és szedimentációval frakcionáltuk. A kísérletekhez a több mint egy hétig nem ülepedő frakciót használtuk, melyek ZetaSizer müszerrel meghatározott ekvivalens átmérője $440 \mathrm{~nm}$ volt. A karbonátoktól megtisztított bentonitot $1 \mathrm{M} \mathrm{NaCl}$ oldattal való ötszörös kezelésnek vetettük alá, majd egy hétig desztillált vízben dializáltuk, amíg a szuszpenzió elektromos vezetése egy állandó értéket nem ért el. A SEM felvételek azt mutatták, hogy a minták kb. 70\% 300-350 nm átlag átmérőjü ,individuális" részecskékből és kb. 30\% 1,0-1,3 $\mu$ m átmérőjü, kissé eltérő formájú aggregátumokból áll. A fenti arányt száz, Na-bentonit részecske méretének összehasonlításából állapítottuk meg. A részecskék alakja inkább gömbökkel, mint pálcika alakú részecskékkel közelíthetők. Az ásvány $\mathrm{BaCl}_{2}$ oldattal megvalósított konduktometriális titrálás alapján meghatározott kation cserélő kapacitása $72 \mathrm{mmol} / 100 \mathrm{~g}$ értéket ért el.

Azelektroforetikus méréseket ZetaSizer Nano ZS(Malvern, UK) müszerrel végeztük szobahőmérsékleten, jellegzetesen 6-15 V/cm térerősségnél. Híg, kis vezetésü elektrolit oldatokban az elektromos tér gradiense (amit a müszer automatikusan szabályoz) 100-150 V/cm-ig növekedett meg. Vizsgáltuk a hozzáadott sav $(\mathrm{HCl})$, lúg $(\mathrm{NaOH}$ vagy $\mathrm{KOH})$ és sók ( $\mathrm{LiCl}, \mathrm{NaCl}, \mathrm{KCl}, \mathrm{RbCl}, \mathrm{CsCl}, \mathrm{Li}_{2} \mathrm{SO}_{4}, \mathrm{Na}_{2} \mathrm{SO}_{4}$, $\mathrm{K}_{2} \mathrm{SO}_{4}, \mathrm{CaCl}_{2}$, és $\mathrm{LaCl}_{3}$ ) hatását a $\mathrm{Na}$-bentonit részecskék elektrokinetikai potenciáljára. A bemutatott értékek 3-6 párhuzamos mérés átlagosított eredménye. A $\zeta$ - potenciál meghatározásának hibahatára $1,5-2,5 \mathrm{mV}$ kis elektrolit koncentrációknál, $C<10^{-3} \mathrm{mól} / \mathrm{L}$, és $0,8-1,2 \mathrm{mV}$ nagyobb koncentrációknál. Az elektroforetikus mozgékonyságok $\zeta$ -potenciálra való konvertálása a klasszikus Smoluchowski egyenlet alapján történt, a müszerbe beépített software alkalmazásával, azaz figyelmen kívül hagyva az elektromos kettősréteg külső elektromos térben (kis ionerősségeknél) felléphető polarizációját. Ezért a bemutatott értékek egy „effektív” $\zeta$-potenciált jelentenek, ami egyenlő az elektro- 
foretikus mozgékonysággal, szorozva a közeg viszkozitása és permittivitása közötti arány értékével. Ez az eljárás széleskörűen elterjedt az irodalomban és jól szolgál összehasonlítási célokra, pl. annak követésére, hogy befolyásolják a különböző változók a részecskék mozgékonyságát és $\zeta-$ potenciálját ${ }^{22,23}$.

\section{Eredmények és értékelésük}

\subsection{Elektrokinetikai potenciál}

\subsubsection{Liofób részecskék}

Liofób polisztirol latex $\left(\mathrm{PS}-\mathrm{SO}_{3} \mathrm{H}\right)$ elektrokinetikai potenciáljának változása az alkáli fém kloridok koncentrációjának függvényében kis sótartalmaknál először a potenciál abszolút (negatív) értékének jelentős növelését mutatja, majd a $\zeta(\mathrm{C})$ görbéken $2-5 \cdot 10^{-4} \mathrm{M}$ koncentráció tartományban maximum jelenik meg (1. ábra). Az $\zeta$ értékek növekedése legnagyobb a $\mathrm{LiCl}$ esetében, a növekedés mértéke a $\mathrm{CsCl}$ felé haladva csökken. A maximum utáni tartományban a só koncentrációjának $5 \cdot 10^{-4} \mathrm{M}$ - tól $10^{-2} \mathrm{M}$-ig való növelése csökkenti a részecskék $\zeta$ - potenciálját, egyre nagyobb mértékben $\mathrm{Li}^{+}$-tól $\mathrm{Cs}^{+}$-ig haladva, azaz a polisztirol részecskék esetében a klasszikus Hofmeister sor figyelhető meg.

A karboxil latex viselkedése hasonlít a fent leírtakhoz azzal a különbséggel, hogy Hofmeister sor képviselöi között mért $\zeta$ - potenciál értékek kisebb eltéréseket mutatnak, mint a szulfát-csoportokat tartalmazó latex esetében (2. ábra). A legjobban hidratált $\mathrm{Li}+$ ionok jelenlétében mért $\zeta(C)$ görbe maximuma nagyobb só-koncentráció tartományba $\left(10^{-3} \mathrm{M}\right)$ tolódik el a kevésbé hidratált kationokra jellemző koncentrációkhoz képest $\left(10^{-4}-2 \cdot 10^{-4} \mathrm{M}\right)$. Ennek az oka feltehetően abban rejlik, hogy a PS-COOH felület liofil jellege erösebb, és köztes helyet foglal el a jellegzetes liofób (direkt Hofmeister sor) és jellegzetes liofil (indirekt Hofmeister sor)

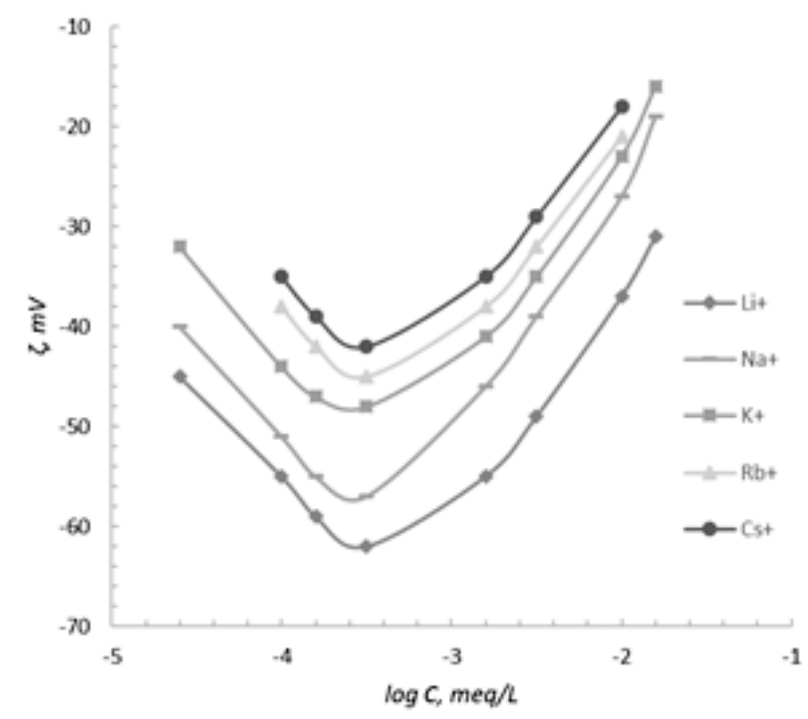

1. ábra. Szulfo-csoportokkal funkcionalizált polisztirol latex elektrokinetikai potenciálja a hozzáadott alkáli fém kloridok koncentrációjának függvényében felületek viselkedése között. A különbségben szerepet játszhat a tárgyalt két felület töltéssürüsége közötti eltérés is.

\subsubsection{Liofil részecskék}

Az alkálifém kloridok hatása a liofil aeroszil részecskék elektroforézisére nem szokványos viselkedést mutatott (3. ábra). Kis, $10^{-3}-5 \cdot 10^{-3} \mathrm{M}$ alatti elektrolit koncentrációknál, fordított liotróp sor figyelhető meg, nevezetesen egyre magasabb (negatív) $\zeta$ - potenciál értékek a $\mathrm{Li}^{+}$-tól $\mathrm{Cs}^{+}$felé haladva. Jelentős só-tartalmaknál ez a sorrend megváltozik, azaz a jobban hidratált kationoknál nagyobb $\zeta$ - potenciál értékeket mértünk, mint ami a direkt Hofmeister sornak felel meg. Feltételezhető, hogy az aeroszil felülete hidratáltságának mértéke tömény elektrolit oldatokban csökken, kevésbé lesz liofil, és viselkedése közelit a liofób felületek, egyenes Hofmeister sorral jellemezhető viselkedéséhez. És fordítva, kis só-tartalmaknál az aeroszil felülete liofil marad, amelyre a fordított liotróp sor érvényes.

A liofil cirkónim dioxid és Laponit mesterséges agyagásvány viselkedése elektromos térben megfelel az aeroszil fent leírt viselkedésének: kis ionerősségeknél a fordított, nagy ionerőségeknél pedig az egyenes liotróp sor figyelhető meg (4 és 5. ábrák).

A 6.ábra alkáli klorid oldatoknak Na-bentonit részecskék $\zeta$ - potenciáljára kifejtett hatását mutatja be. Az alábbi törvényszerüségekre hívjuk fel a figyelmet:

(i) a $\zeta$ - potenciál abszolút (negatív) értékei a só tartalmának függvényében a jól hidratált $\mathrm{Li}^{+}, \mathrm{Na}^{+}$és $\mathrm{K}^{+}$ionok esetében, $\mathrm{C} \sim 10^{-2} \mathrm{~mol} / \mathrm{L}$ koncentráció tartományban maximumot mutatnak. Kevésbé hidratált $\mathrm{Rb}^{+}$és $\mathrm{Cs}^{+}$ionoknál széles koncentráció tartományban $\left(10^{-5-}-10^{-3} \mathrm{M}\right)$ változatlan $\zeta$-potenciál értékeket regisztráltunk.

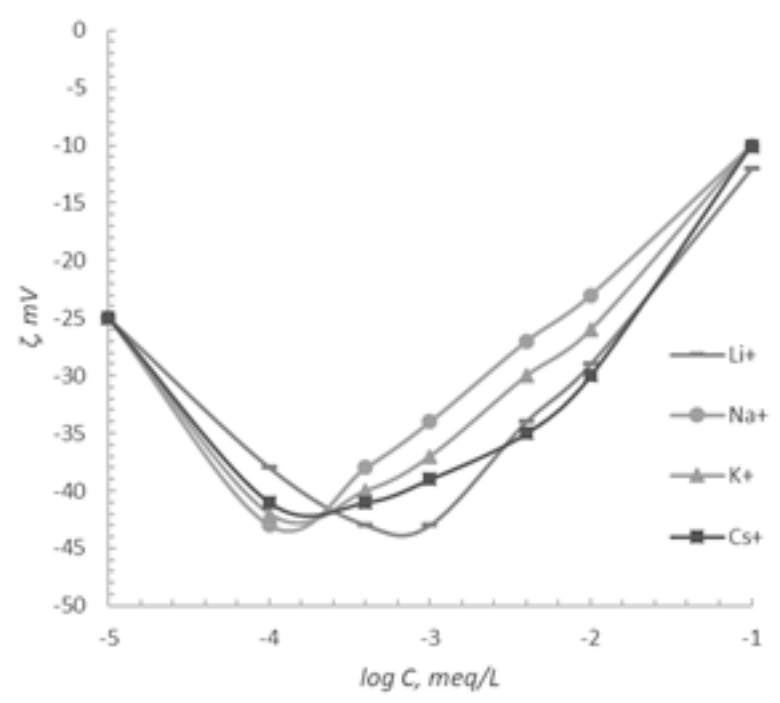

2. ábra. Karboxil latex elektrokinetikai potenciája a hozzáadott LiCl, $\mathrm{NaCl}, \mathrm{KCl}$ és $\mathrm{CsCl}$ koncentrációjának függvényében 
(ii) széles koncentráció intervallumban $\left(10^{-5}-10^{-1} \mathrm{~mol} / \mathrm{L}\right)$ az alkáli kloridok viselkedése megfelel az egyenes Hofmeister sor szerint elvártnak. Jelentős különbségek a $\zeta$-potenciál értékekben tömény só-oldatokban $\left(C \approx 10^{-2}-10^{-1} \mathrm{M}\right)$ figyelhetők meg, azaz amikor az ásványfelület dehidratált.

(iii) $\mathrm{A} \mathrm{KCl}$ hozzáadásakor mért $\zeta(C)$ görbék lefutása $10^{-}$ ${ }^{5}-10^{-3} \mathrm{M}$ só-tartalmaknál egybeesik a $\mathrm{Rb}^{+}$ionok esetében megfigyelt megfelelö görbével. Ez azt jelenti, hogy a $\mathrm{K}^{+}$ionok a felülethez nagyobb affinitással rendelkeznek, mint ez várható ennek a liotróp sorban elfoglalt helyéböl. A jelenség a $\mathrm{K}^{+}$ionoknak az agyagásvány kristályrácsába való beépülésével magyarázható ${ }^{26}$.

\subsubsection{Szulfát ko-ionok hatása}

Ismeretes, hogy a szulfát ionok jelentős dehidratálási képességgel rendelkeznek ${ }^{27}$ Célszerünek tünt alkálifém kloridok és szulfátok elektroforézisre kifejtett hatásának öszszehasonlító vizsgálata, ami alapján értékelhető, milyen mértékben befolyásolják a szulfát ko- ionok a határfelület hidratáltságának mértékét. Példaképpen a 7. ábra bemutatja, Na- bentonit részecskék elektrokinetikai potenciáljának változásait lítium vagy kálium kloridok és szulfátok ekvivalens koncentrációjának függvényében. Hasonló változásokat figyeltünk meg $\mathrm{SiO}_{2}$ vagy laponit szuszpenziók $\zeta$ - potenciáljában alkáli fém kloridok és szulfátok jelenlétében. Látható, hogy a szulfát anionokat tartalmazó alkálifém sók - széles koncentráció tartományban - lényegesen nagyobb $\zeta$ - potenciál értékeket eredményeznek, mint a kloridok. Ezt azzal magyaráztuk, hogy a szulfát ionok a felület-közeli rétegre dehidratáló hatást fejtenek ki, ami a hasadási síknak a felület felé való eltolódását és a $\zeta$ - potenciál növekedését idézi elő.

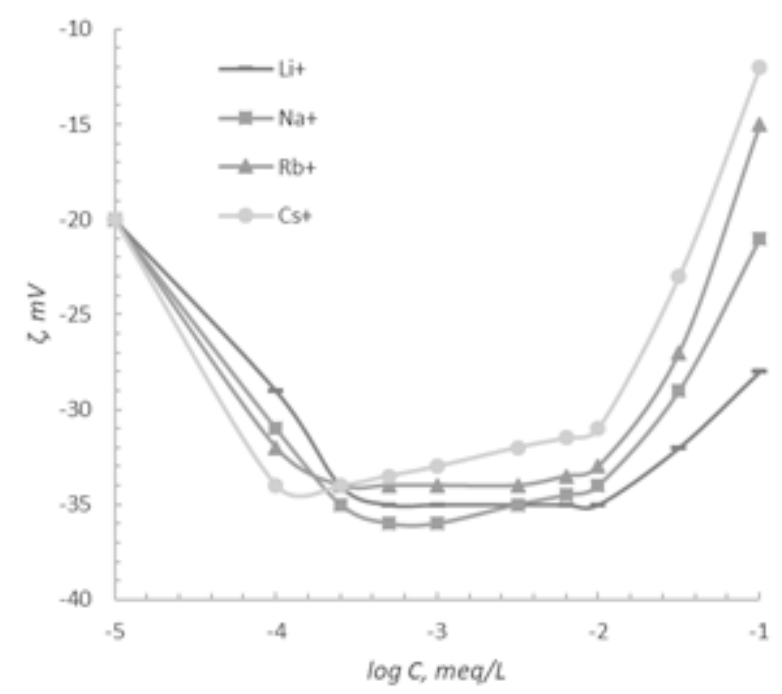

3. ábra. Aeroszil részecskék elektrokinetikai potenciálja a hozzáadott $\mathrm{LiCl}, \mathrm{NaCl}, \mathrm{RbCl}$ és $\mathrm{CsCl}$ koncentrációjának függvényében

A bemutatott eredményekböl látható, hogy alkáli fém kloridok vagy szulfátok hozzáadása liofób részecskéknél $\mathrm{C}=5.10^{-4}-10^{-3} \mathrm{M}$ és liofil részecskék estében $\mathrm{C}=10^{-3}-10^{-2} \mathrm{M}$ tartományban maximumot mutató $\zeta(C)$ függvények megjelenéséhez vezet. Egyes esetekben (bentonit, $\mathrm{ZrO}_{2}$ kis mennyiségü $\mathrm{RbCl}, \mathrm{CsCl}$ jelenlétében) állandó zéta-potenciál értéket mértünk. Hasonló, maximumot vagy széles só-koncentráció tartományban állandó értéket mutató $\zeta(C)$ függvényeket számos diszperzió esetében megfigyeltek. Ezekhez tartoznak egyes latexek, fémoxidok, agyagásványok, baktérium- és élesztősejtek, olaj/viz emulziók (lásd $\mathrm{pl}^{22,23}$ ). A korábbi kutatásokban a $\zeta$ - potenciál növekedését az egytöltésű ellenionok tartalmának emelésével a ko-ionok adszorpciójával és az ezzel bekövetkező felületi töltés növekedésével magyarázták. Ugyanakkor ez az elképzelést nem nyert kísérleti bizonyítást ${ }^{22,28}$. Hasonlóképpen, Elemelich és O.Melia feltételezték, hogy a polisztirol latex részecskék elektroforetikus mozgékonyságának növekedése a só-koncentráció emelésével a ko-ionoknak a liofób felületen való felhalmozódásának következménye ${ }^{29}$. A mi elképzelésünk szerint a $|\zeta|$ maximumot mutató viselkedése kis ionerősségeknél az elektromos kettős réteg külső elektromos térben megvalósuló polarizációjával hozható összefüggésbe. Az EKR polarizációja indukált dipólus megjelenéséhez vezet, amely orientációja ellentétes a külső tér irányához viszonyítva. Az indukált dipólus momentum nagysága arányos az elektromos tér erősségével és a részecske sugarának köbével ${ }^{22,30}$. Az elektrolit koncentráció csökkenésével az EKR kiterjedése és deformációja, valamint a ZetaSizer által generált (automatikusan szabályozott) térerősség és ennek megfelelöen a dipólus momentum értéke növekszik. Mindez a részecskék növekvő fékezését idézi elő. Ez magyarázza a görbék leszálló ágát a maximum bal oldalán. Az ionerösség növelésével az EKR zsugorodása túlkompenzálja a fenti effektust és az $\zeta$-potenciál csökkenését idézi elö. Megjegyzendő, hogy a $\zeta(C)$ maximumot mutató függvényei akkor jelennek meg, ha az elektroforetikus mozgékonyságot a Smoluhowski vagy Hückel-féle összefüggések szerint, azaz az EKR diffúz részé polarizációjának elhanyagolásával számítjuk át $\zeta$-potenciál értékké.

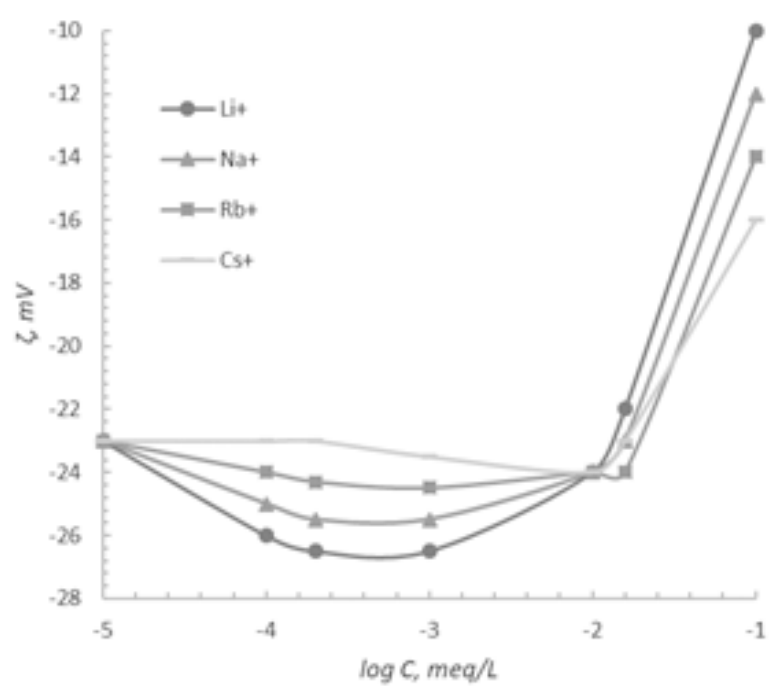

4. ábra. Cirkónium dioxid részecskék elektrokinetikai potenciálja a hozzáadott $\mathrm{LiCl}, \mathrm{KCl}, \mathrm{RbCl}$ és $\mathrm{CsCl}$ tartalmának függvényében 


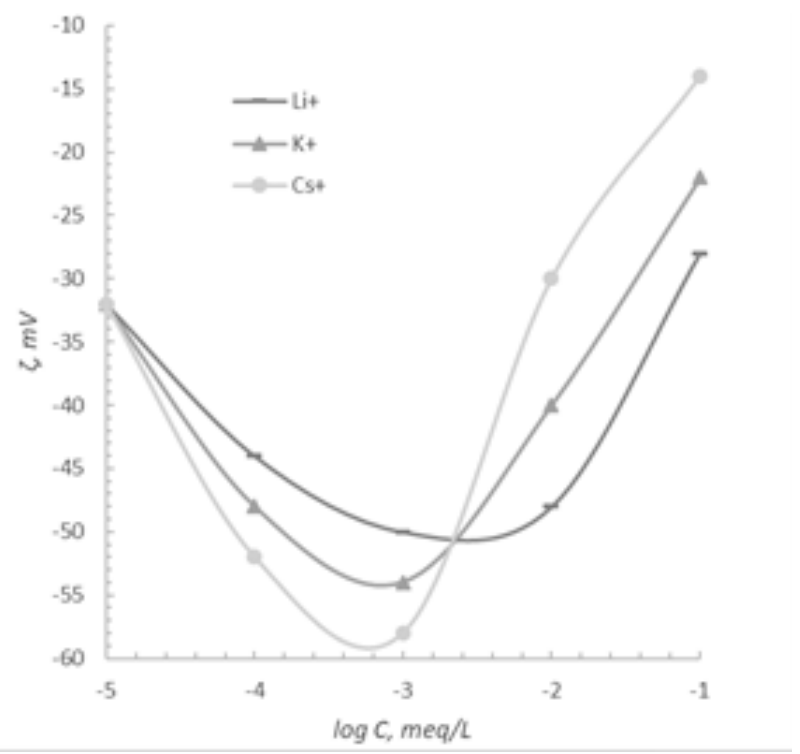

5. ábra. Laponit részecskék elektrokinetikai potenciálja a hozzáadott $\mathrm{LiCl}, \mathrm{KCl}$ és $\mathrm{CsCl}$ tartalmának függvényében

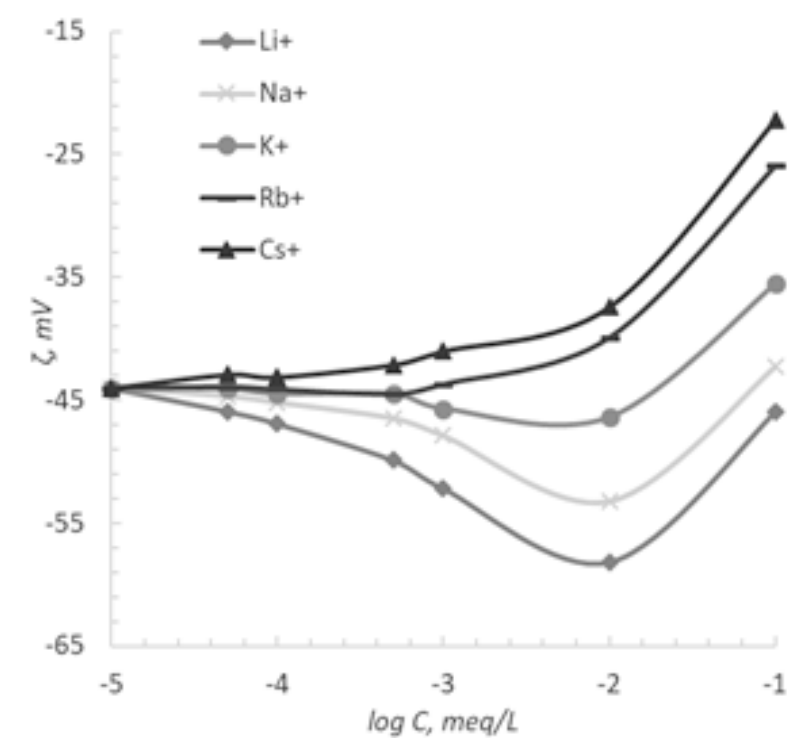

6. ábra. Na-bentonit elektrokinetikai potenciálja a hozzáadott alkáli klorid sók koncentrációjának függvényében

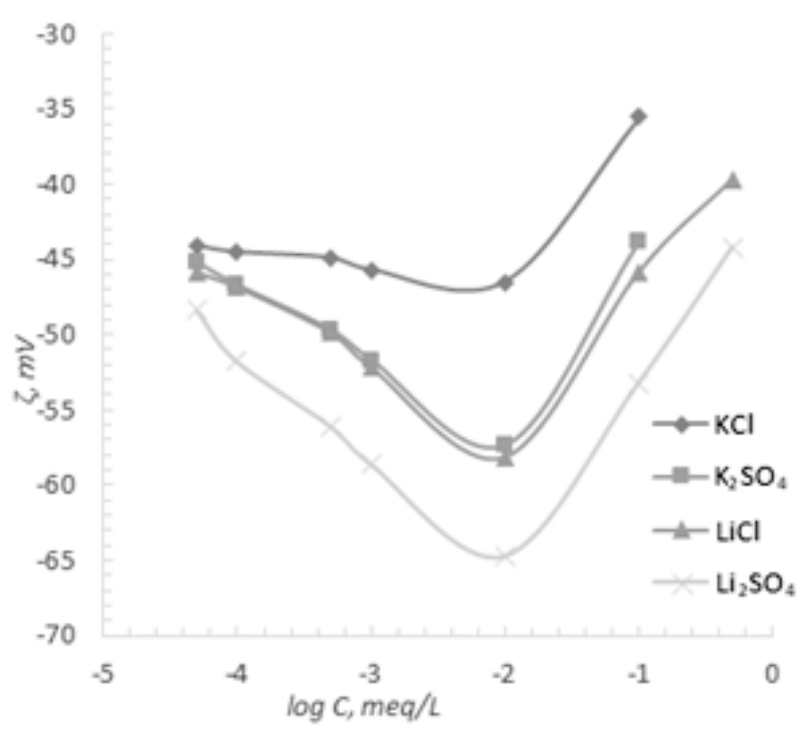

7. ábra. Na-bentonit elektrokinetikai potenciálja a hozzáadott lítium vagy kálium klorid és szulfát ekvivalens koncentrációjának függvényében

Az alkálifém sók elektrokientikai potenciálra kifejtett hatásának tárgyalásakor a fentieken kívül figyelembe kell venni a kettősrétegben lejátszódó ioncsere folyamatokat is. Az agyagásványok külső fegyverzete, $\mathrm{Na}^{+}$- ionjainak kicserélése kevésbé hidratált $\mathrm{K}^{+}, \mathrm{Rb}^{+}$vagy $\mathrm{Cs}^{+}$ionokra, a Stern-réteg nagyobb sugarú ellenionokkal való növekvő telitettségéhez vezet, ami jelentősen csökkenti a $\zeta$-potenciál értékét. Ugyanakkor a jól hidratált $\mathrm{Na}^{+}$ionok megjelenése az oldatban az EKR tágulásához vezet, azaz ellentétes effektus okozója. Ellenkező tendenciákat figyelünk meg a legjobban hidratált $\mathrm{Li}^{+}$ionok esetében. A $\zeta$ - potenciál változásai a fent ismertetett sokféle, ellentétes irányba ható folyamatok eredője. Ezek tárgyalását a felületi vezetés adataival kiegészítve, a következő cikkünkben folytatjuk.

\section{Köszönetnyilvánítás}

A kutatómunka a Miskolci Egyetemen müködő Alkalmazott Földtudományi Kutatóintézet GINOP-2.3.2-15-2016-00010 jelü „Földi energiaforrások hasznosításához kapcsolódó hatékonyság növelö mérnöki eljárások fejlesztése" projektjének részeként - a Széchenyi 2020 program keretében - az Európai Unió támogatásával, az Európai Strukturális és Beruházási Alapok társfinanszírozásával valósult meg. 


\section{Hivatkozások}

1. Lyklema J. Fundamentals of Interface and Colloid Sciences, vol. I, Academic Press Ltd: London, 1993.

2. Zhang, Y., Cremer, P.S. Annu. Rev.Phys. Chem., 61, 63-83. 2010.

https://doi.org/10.1146/annurev.physchem.59.032607.093635

3. Kunz, W. Specific ion effects, evidences, Encycl. Appl. Electrochem, Springer 2045-2050. 2014.

https://doi.org/10.1007/978-1-4419-6996-5 26

4. Kallay, N., Čolić, M., Fuerstenau, D.W., Jang, H.M., Matijević, E. Colloid and Polymer Science, 272, (5) 554-561. 1994. https://doi.org/10.1007/BF00653221

5. Bastos-Gonzales D., Perez-Fuentes L., Drummond C., Faraudo J. Current Opinion in Colloid a. Interf. Sci., 23. 19-29. 2016. https://doi.org/10.1016/j.cocis.2016.05.010

6. Omta A., Kropman M., Woutersen S., Bakker H. Science 301 (5631) 347-349. 2003. https://doi.org/10.1126/science. 1084801

7. Gurau M., Lim S., Castellana E., Albertorio F., Kataoka S., Cremer P. J. Am. Chem. Soc. 126 (34) 10522-10523. 2004. https://doi.org/10.1021/ja047715c

8. Lyklema, J. Chem. Phys. Lett. 467 (4-6) 217-222. 2009. https://doi.org/10.1016/j.cplett.2008.11.013

9. Boström M., Tavares F., Finet S., Skouri-Panet F., Tardieu A., Ninham B. Biophys. Chem., 117 (3): 217-224. 2005. https://doi.org/10.1016/j.bpc.2005.05.010

10. Zhang Y., Cremer P.S. Proc. Nat Acad. Sci. USA, 36. 1524953. 2009. https://doi.org/10.1146/annurev.physchem.59.032607.093635

11. Baldwin R. Biophys. J. 71(4) 2056-2063. 1996. https://doi.org/10.1016/S0006-3495(96)79404-3

12. Schwierz N., Horinek D., Netz R.R. Langmuir 29 (8) 2602 2614. 2013. https://doi.org/10.1021/la303924e

13. Franks, G.V. J. Coll.Interf.Sci.,249(1), 44-51. 2002. https://doi.org/10.1006/jcis.2002.8250

14. Morag J.,Dishon M., Sivan U. Langmuir, 29 (21) 6317-6322. 2013. https://doi.org/10.1021/la400507n

15. Saka E.E., Güler C. Clay Minerals, 41(4). 853-861. 2006. https://doi.org/10.1180/0009855064140223
16. Kallay, N., Čolić, M., Fuerstenau, D.W., Jang, H.M., Matijević, E. Colloid Polymer Sci., 272. 554-561. 1994. https://doi.org/10.1007/BF00653221

17. López-León, T., Santander-Ortega, M.J., Ortega-Vinuesa, J.L., Bastos-González, D. J. Phys.Chem. C 112 (41). 1606016069. 2008. https://doi.org/10.1021/jp803796a

18. Boström M., Tavares F., Finet S. et.al. Biophys. Chem., 117 (3). 217-224. 2005 https://doi.org/10.1016/j.bpc.2005.05.010

19. Flores S.C. Kherb J., Konelick N., Chen X., Cremer P.S. J. Phys. Chem., 116 (27). 14408-13. 2012. https://doi.org/10.1021/jp210791j

20. Morag J., Dishon M., Sivan U. Langmuir, 29. 6317-22. 2013. https://doi.org/10.1021/la400507n

21. Schwierz, D.Horinek, D. Sivan, U. Netz, R. Current Opinion Colloid Interf Sci. 23. 10-18. 2016. https://doi.org/10.1016/j.cocis.2016.04.003

22. Bárány S. Adv. Colloid Interf. Sci., 75. 45-75. 1998. https://doi.org/10.1016/S0001-8686(97)00043-2

23. Baran A.A., Dudkina L.M., Soboleva N.M., Chechik O.S. Colloid J. of the USSR, 43. 211-219. 1981.

24. Thompson, D.W. Butterworth, J.T. J. Colloid Interface Sci. ,151, 236-243. 1992. https://doi.org/10.1016/0021-9797(92)90254-J

25. Manilo, M., Lebovka, N., Barany, S. Colloids Surf. A., 462. 211-216. 2014. https://doi.org/10.1016/j.colsurfa.2014.09.006

26. Filep G.. Talajkémia. Akadémiai Kiadó Bp. 1988.

27. Solomentseva I., Barany S., Gregory J. Colloids Surf.A., 230. 117-129. 2003. https://doi.org/10.1016/j.colsurfa.2003.09.019

28. Glazman Yu.,Strazhesko N.,Tartakovskaya E. Colloid J.of the USSR, 15. 161-169. 1953.

29. Elimelech, M., O’Melia, C.R. Colloids Surf. A, 44. 165-178. 1990.

https://doi.org/10.1016/0166-6622(90)80194-9

30. Dukhin, S. Adv. Colloid Interf. Sci. 44. 1-134. 1993. https://doi.org/10.1016/0001-8686(93)80021-3 


\section{Electrosurface properties of hydrophobic and hydrophilic suspensions: validity of the Hofmeister series. I Electrokinetic potential}

The results of systematic study of the impact of electrolytes (in a wide range of electrolyte concentration, $\mathrm{C}=10^{-5}-10^{-1} \mathrm{M}$ ) with alkali metal ions $(\mathrm{Li}+, \mathrm{Na}+, \mathrm{K}+, \mathrm{Rb}+, \mathrm{Cs}+)$ containing chlorides and sulphate anions on the electrokinetic potential, $\zeta$, of aqueous suspensions containing hydrophobic (polystyrene latex with surface sulphate or carboxylic groups) and hydrophilic (aerosil, zirconium dioxide, Na-bentonite, Laponite $\mathrm{RD}^{\circledR}$ ) particles are presented.

The most important literature data and theoretical considerations on the impact of the ions nature and degree of their hydration on the electrokinetic potential of colloids are discussed. It is stressed that there is no unique Hofmeister series for the electrophoretic mobility, it can depend on the nature of the surface involved (sign of charge, polarity, hydrophilic or hydrophobic nature, etc.), type of electrolyte, $\mathrm{pH}$, temperature and other conditions of the experiment. Depending on the parameters, the ordering of the ions within the Hofmeister series can be direct, indirect and partially altered. The nature/hydration of ions strongly influences the $\zeta$-potential and surface conductivity of colloids mainly by two mechanisms: (i) the least hydrated (the so-called structure breaker, e.g. $\mathrm{Cs}+$ ) ions adsorb better, occasionally in larger amounts compared to the most hydrated (the so-called structure maker, e.g., $\mathrm{Li}+$ ) ions. They are increasingly accumulated in the Stern layer and it results in substantial decrease of the electrophoretic mobility; (ii) the degree of the surface hydration can determine the position of the slip plane and, consequently, has impact on the $\zeta$-potential. Both the electrostatic and non-electrostatic interactions may play a role. The contribution of short-range and long-range forces in the specific interactions of ions and the surface is discussed. Examples of the validity of direct or reverse Hofmeister series in specific systems are considered.

The methods of synthesis/sources of purchase, size, specific surface area and the value of the surface charge density of particles under study are described.

The observed $\zeta(\mathrm{C})$ dependencies revealed marked maxima at $\mathrm{C}=$ $10^{-4}-10^{-3} \mathrm{M}$ for hydrophobic and at $\mathrm{C}=10^{-3}-10^{-2} \mathrm{M}$ for hydrophilic particles. This phenomenon was explained accounting for two opposite trends related to the polarization of the electrical double layer (EDL) in the external electric field (increase of $\zeta$-potential at low concentration) and the effect of the EDL compression (decrease of $\zeta$-potential at high concentration).

The EDL polarization in the external electric field results in appearance of induced dipoles that are oriented oppositely to the direction of the electric field, i.e. they exert retarding effect to the particles movement. The induced dipole moment is proportional to the external field and the third power of the particles radius. As the ionic strength decreases, the EDL thickness and the degree of its deformation increases, and the applied electric field (regulated by the Zeta Sizer device automatically) also increases. This gives a rise to the magnitude of the induced dipole moment, which lowers the particles mobility. Also it is shown that in concentrated solutions $\left(\mathrm{C}>10^{-3}-10^{-2} \mathrm{M}\right) \zeta$-potentials always decreased regularly in the direct Hofmeister series from $\mathrm{Li}+$ to $\mathrm{Cs}+$ cations. This is explained by the fact that transition from $\mathrm{Li}+$ to $\mathrm{Cs}+$ cations leads to a decrease both the concentration of ions in the diffuse layer and the induced dipole moments, and its results in weaker retardation of particle movement in the electric field. This is in line with the majority of previously published data. However, in more diluted solutions, the indirect Hofmeister series for hydrophilic particles were also observed. Such behaviour can reflect the impact of different properties of the surface including hydrophilic or hydrophobic nature, charge density, and partial dehydration.

In the event of clay minerals (Na-bentonite, Laponite RD) also the ion-exchange, i.e. the substitution of exchangable Na-ions by less hydrated $\mathrm{K}+, \mathrm{Rb}+$ or $\mathrm{Cs}+$ ions should be taken into account. This results in increasing filling up the Stern-layer by bigger counter-ions which reduces the Stern- and zeta-potential values. The run of $\zeta(\mathrm{C})$ curves at addition of equivalent amounts of $\mathrm{KCl}$ and $\mathrm{RbCl}$ to Na-bentonite suspensions coincided, which is the evidence of high affinity of $\mathrm{K}+$-ions to the mineral lattice comparable to that for cations of bigger radius.

The sort of anions also influenced the value of $\zeta$-potential, namely, the electrokinetic potential of particles in alkali metal sulphates solutions was found to be higher compared to that for chlorides at equivalent concentration of salts. This phenomenon was explained by dehydration effect of sulphate ions, thinning the surface hydrate layer and shift of the shear plane toward the surface. 